\title{
Gonadotrope responsiveness in orchidectomized sheep: effect of duration of a simulated follicular phase
}

\author{
H. Sakurai, B. M. Adams and T. E. Adams* \\ Department of Animal Science, University of California Davis, CA 95616, USA
}

\begin{abstract}
The effect of duration of a simulated follicular phase on gonadotrope responsiveness was assessed in orchidectomized sheep (wethers). The oestrogenic and hypothalamic inputs characteristic of the ovine follicular phase were simulated by continuous infusion of oestradiol $\left(5 \mu \mathrm{g} \mathrm{h}^{-1}\right.$ in $10 \%(\mathrm{v} / \mathrm{v})$ ethanol-saline) and circhoral delivery of GnRH (200 $\mathrm{ng}$ per hourly pulse) for $0,6,12,24,48$ or $96 \mathrm{~h}$ ( $n=6$ wethers per group). Responsiveness increased $(P<0.05)$ with increasing duration of simulated follicular phase. In a second experiment, responsiveness was assessed $96 \mathrm{~h}$ after initiation of infusion of oestradiol in wethers receiving hourly pulses of $\mathrm{GnRH}$ or saline. Concurrent administration of GnRH reduced $(P<0.05)$ the magnitude of the oestradiol-induced increase in gonadotrope responsiveness. In a companion study, anterior pituitary tissue was collected $96 \mathrm{~h}$ after the start of infusion of oestradiol and circhoral delivery of GnRH or saline. Pituitary stores of $\mathrm{LH}$ and tissue concentrations of $\mathrm{GnRH}$ receptor and mRNA encoding the GnRH receptor were increased $(P<0.05)$ by oestradiol infusion. The magnitude of these oestradiol-induced responses was not affected $(P>0.05)$ by concurrent $\mathrm{GnRH}$ treatment. Tissue concentrations of FSH and mRNA encoding the FSH $\beta$ subunit were decreased $(P<0.05)$ by oestradiol infusion. This suppressive effect of oestradiol was not reversed by GnRH. These results indicate that oestradiol stimulation, but not concurrent delivery of $\mathrm{GnRH}$, is essential for full expression of surge-like secretion of LH. In addition, the oestradiol-induced increase in gonadotrope responsiveness during the simulated follicular phase is sustained throughout the period of oestradiol delivery.
\end{abstract}

\section{Introduction}

In previous studies we have used oestradiol-treated orchidectomized sheep (wethers) to characterize the pattern of $\mathrm{GnRH}$ stimulation required to induce preovulatory surge-like secretion of LH (Sakurai and Adams, 1991; Sakurai et al., 1993a). The results of these studies suggest that surge-like secretion of LH is induced by an abrupt increase in the amplitude of the circhoral GnRH stimulus. This pattern of GnRH delivery is referred to as the 'stimulus-shift' paradigm. This regimen of GnRH or GnRH agonist delivery involves a period of low amplitude stimulation that simulates the pattern of $\mathrm{GnRH}$ secretion during the follicular phase (Moenter et al., 1991). Ovulatory surge-like secretion of the gonadotrophins is induced by an eight-fold increase in the amplitude of the circhoral GnRH or GnRH agonist input. The physiological relevance of this paradigm has been demonstrated in female sheep in which endogenous $\mathrm{GnRH}$ has been neutralized by passive immunization (Sakurai et al., 1992). Moreover Moenter et al. $(1990,1991)$ have characterized a pattern of GnRH secretion during the periovulatory period in ewes that is similar to the stimulus-shift paradigm of $\mathrm{GnRH}$ administration.

${ }^{*}$ Correspondence.

Received 28 February 1996.
Oestrogenic stimulation during the simulated follicular phase is a critical determinant of gonadotrope responsiveness. Indeed, the surge-like secretion of LH induced in wethers and ewes at stimulus-shift is blunted in the absence of oestrogenic stimulation, or after oestradiol withdrawal (Sakurai et al., 1992, 1993a, b). Oestradiol secretion during the follicular phase of the oestrous cycle is the product of an endocrine cascade that begins at the hypothalamus with episodic secretion of $\mathrm{GnRH}$. In addition to sustaining gonadotrophin release and promoting oestradiol secretion from the developing Graafian follicle, low amplitude GnRH stimulation during the natural or simulated follicular phase may also directly affect gonadotrope responsiveness. Clarke and Cummins (1987) reported that episodic low-amplitude GnRH stimuli augmented gonadotrope responsiveness by supporting LH and FSH synthesis and maintaining tissue stores of these hormones. Indeed, pulsatile delivery of $\mathrm{GnRH}$ increases the concentration of mRNA encoding the gonadotrophin subunits in pituitary tissue and augments tissue concentrations of GnRH receptor (Leung et al., 1987; Hamernik and Nett, 1988). Furthermore, Phillips et al. (1990) suggested that low-amplitude GnRH stimulation during the follicular phase plays a key role in determining the magnitude of the secretory response induced by an abrupt increase in the amplitude of the GnRH stimulus. Taken together, these studies suggest that the augmentation of gonadotrope responsiveness 
that is essential for full expression of the GnRH-induced preovulatory surge of gonadotrophins is the product of oestrogenic stimulation and circhoral stimulation by low amplitude GnRH.

In the study reported here the relative contributions of oestradiol and low amplitude GnRH stimulation to the enhancement of gonadotrope responsiveness that occurs during the simulated follicular phase is examined. We hypothesized that pulsatile delivery of low amplitude GnRH would increase gonadotrope responsiveness in oestradiol-treated wethers. In addition, we postulated that increasing the duration of the simulated follicular phase would lead to corresponding increases in gonadotrope responsiveness.

\section{Materials and Methods}

\section{Animals}

Crossbred whiteface sheep were castrated within 2 weeks of birth. The orchidectomized lambs (wethers) were housed in an open-sided barn under natural lighting and were afforded free access to water and alfalfa pellets supplemented with cereal grains and vitamin and mineral premix. The studies described here were conducted in early spring, a period of transition between the breeding and anoestrous seasons in female sheep at this latitude $\left(38^{\circ} \mathrm{N}\right)$. The wethers were $6-8$ months of age (mass $=45-50 \mathrm{~kg}$ ) at the time of experimentation. All experimental procedures involving the use of animals were conducted in accordance with National Institutes of Health (NIH) Guidelines and were reviewed and approved by the Animal Use and Care Committee for the University of California.

\section{Cannulation}

Before experimentation, two polyethylene cannulae (Intramedic PE 100, Clay Adams, Parsippany, NJ) were inserted into the left jugular vein to serve as hormone delivery cannulae (oestradiol or GnRH). A third cannula (Intramedic PE 190), inserted into the contralateral vein, was used for collection of blood samples. All cannulae were passed through a protective Tygon tubing sheath to the exterior of the animal holding area. Animals were freely mobile at the end of a $1 \mathrm{~m}$ lead.

\section{Hormone delivery}

Cannulae for the delivery of oestradiol or vehicle were connected to syringes placed in Harvard infusion pumps (Model 2265, Harvard Bioscience, South Natick, MA). Oestradiol (5 $\mu \mathrm{g} \mathrm{ml}^{-1}$; Sigma Chemical Co., St Louis, MO) in 10\% $(\mathrm{v} / \mathrm{v})$ ethanol-saline (vehicle), or vehicle alone, was continuously infused at a rate of $1 \mathrm{ml} \mathrm{h}^{-1}$. Serum concentrations of oestradiol were increased to $27.9 \pm 4.5 \mathrm{pg} \mathrm{ml}^{-1}$ within $1 \mathrm{~h}$ of initiation of oestradiol infusion and remained at that concentration for the duration of oestradiol delivery. In contrast, serum concentrations of oestradiol were not detectable $\left(<0.6 \mathrm{pg} \mathrm{ml}^{-1}\right)$ in wethers receiving vehicle alone.

An episodic pattern of delivery of GnRH (200 or $1600 \mathrm{ng}$ per hourly pulse) in saline, or saline alone, was effected using an infusion pump connected to an automatic timer (Chrontrol, Lindburg Enterprises, San Diego, CA) which was programmed to deliver a $5 \mathrm{~min}$ pulse ( $1 \mathrm{ml}$ volume) once each hour. During episodic administration of $\mathrm{GnRH}$, blood samples were collected immediately before GnRH delivery.

\section{Experiment 1}

Oestrogenic and hypothalamic inputs characteristic of the follicular phase were simulated in wethers by continuous infusion of oestradiol and circhoral delivery of low amplitude GnRH. The effect of duration of the simulated follicular phase on gonadotrope responsiveness was determined. Thirty-six wethers were separated at random into 6 treatment groups ( $n=6$ animals per group). Infusion of oestradiol and episodic delivery of $\mathrm{GnRH}$ ( $200 \mathrm{ng}$ per hourly pulse) were continued for $6,12,24,48$ or $96 \mathrm{~h}$ in groups B-F, respectively. Gonadotrope responsiveness was assessed at the end of the period of low amplitude GnRH treatment by increasing the amplitude of the GnRH stimulus to $1600 \mathrm{ng}$ per hourly pulse (stimulus-shift). High amplitude stimulation was continued for $24 \mathrm{~h}$. Oestradiol infusion was maintained throughout the GnRH delivery period. In treatment group $\mathrm{A}$, gonadotrope responsiveness was assessed in animals that had not been previously treated with either oestradiol or low amplitude GnRH. Blood samples were collected at intervals of $2 \mathrm{~h}$ during the first $12 \mathrm{~h}$ of the simulated follicular phase and at $6 \mathrm{~h}$ intervals thereafter. During high amplitude GnRH stimulation blood samples were collected at $2 \mathrm{~h}$ intervals. Serum was harvested and stored frozen at $-20^{\circ} \mathrm{C}$ for later endocrine analysis.

\section{Experiment 2}

The effect of episodic delivery of low amplitude GnRH or continuous infusion of oestradiol or both factors on gonadotrope responsiveness was examined in another experiment. Eighteen wethers were divided into 3 groups $(n=6$ wethers per group). Animals in groups $2 \mathrm{~A}$ and $2 \mathrm{~B}$ received oestradiol $\left(5 \mu \mathrm{g} \mathrm{h}^{-1}\right)$ as a continuous infusion for $120 \mathrm{~h}$. Circhoral delivery of saline (group 2A) or low amplitude GnRH (200 ng per hourly pulse, group 2B) was initiated at the beginning of oestradiol infusion and continued through the first $96 \mathrm{~h}$ of infusion. Gonadotrope responsiveness was assessed during the final $24 \mathrm{~h}$ of infusion by episodic delivery of a high amplitude stimulus (1600 ng GnRH per hourly pulse). Control animals (group 2C) were infused with the oestradiol delivery vehicle and received hourly pulses of saline during the $96 \mathrm{~h}$ period before stimulus-shift. Blood samples were collected at intervals of $2 \mathrm{~h}$ during the first $12 \mathrm{~h}$ of the $96 \mathrm{~h}$ simulated follicular phase and at intervals of $6 \mathrm{~h}$ thereafter. During high amplitude GnRH stimulation blood samples were collected at intervals of $2 \mathrm{~h}$. Serum was harvested and stored frozen at $-20^{\circ} \mathrm{C}$ for later hormone analysis.

\section{Experiment 3}

The effect of episodic delivery of low amplitude GnRH or continuous infusion of oestradiol or both factors on anterior pituitary function was assessed in a companion study. Eighteen 

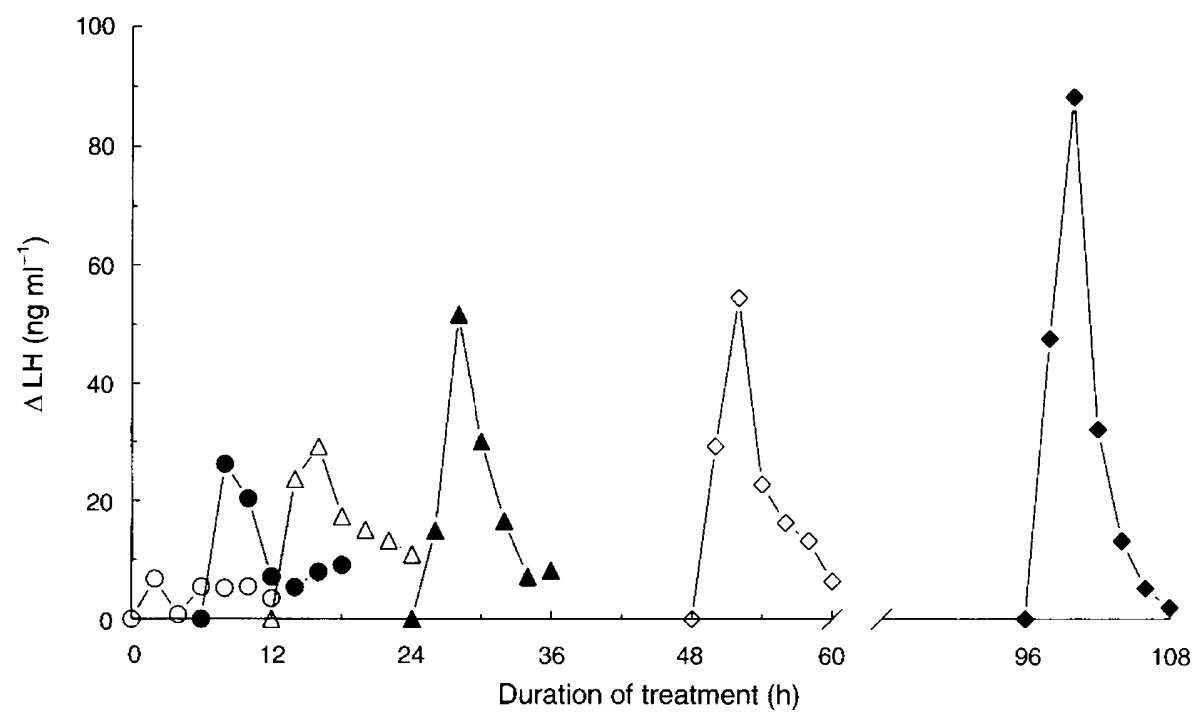

Fig. 1. Gonadotrope responsiveness in wethers $(n=6$ animals per group) $0(0), 6(0), 12(\triangle), 24$ $(\Delta), 48(\diamond)$, or $96(\diamond) \mathrm{h}$ after the start of continuous infusion of oestradiol $\left(5 \mu \mathrm{g} \mathrm{h}^{-1}\right)$ and concurrent episodic delivery of low amplitude GnRH (200 ng per hourly pulse). The increase in

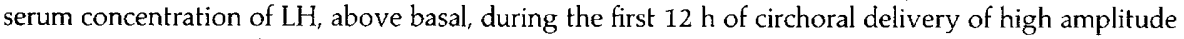
$\mathrm{GnRH}$ (1600 ng per hourly pulse) was taken as a measure of gonadotrope responsiveness. Error bars have been omitted for clarity.

wethers were divided into 3 groups ( $n=6$ wethers per group). Animals in groups $3 \mathrm{~A}$ and $3 \mathrm{~B}$ received oestradiol $\left(5 \mu \mathrm{g} \mathrm{h}{ }^{-1}\right)$ as a continuous infusion for $96 \mathrm{~h}$. Circhoral delivery of saline (group $3 \mathrm{~A}$ ) or low amplitude GnRH (200 ng per hourly pulse, group $3 \mathrm{~B}$ ) was continued throughout the period of oestradiol infusion. Control animals (group $3 \mathrm{C}$ ) were infused with the oestradiol delivery vehicle and received hourly pulses of saline for $96 \mathrm{~h}$. At the conclusion of the $96 \mathrm{~h}$ infusion period, animals were stunned by means of a captive bolt pistol and killed by exsanguination at the UC Davis Slaughter Facility. Anterior pituitary tissue was quickly excised, halved by a midsagittal cut and each half was immediately frozen in liquid nitrogen and stored at $-70^{\circ} \mathrm{C}$ for later analysis.

\section{Endocrine analysis}

Serum and tissue concentrations of LH and FSH, and serum concentrations of oestradiol were determined using previously validated procedures (Adams et al., 1975, 1988; Sakurai et al., 1992). The LH and FSH reference standards (NIAMDDoLH-23 and NIAMDD RP-1) were gifts from the National Hormone and Pituitary Program of the National Institute of Arthritis, Metabolism, and Digestive Diseases (NIAMDD; Baltimore, MD). In all cases intra- and inter-assay coefficients of variation were less than $10 \%$.

The affinity and tissue concentration of GnRH receptors were quantified by means of the procedure described previously (Sakurai and Adams, 1991). Tissue concentrations of mRNA encoding the GnRH receptor or the gonadotrophin subunits were determined via the solution hybridization procedures described previously (Sakurai et al., 1993b; Adams et al., 1996). Plasmids containing cDNA inserts for the bovine $\alpha$ (Erwin et al., 1983), LH $\beta$ (Maurer, 1985) and FSH $\beta$ (Maurer and Beck, 1986) subunits were kindly provided by R. Maurer
(Department of Cell Biology and Anatomy, Oregon Health Sciences University, Portland, OR). A plasmid containing the cDNA insert for the ovine GnRH receptor (Brooks et al., 1993) was kindly provided by J. Brooks (MRC Reproductive Biology Unit, Edinburgh). The sense and anti-sense cRNAs were generated from linearized cDNA by transcription in vitro using either T7 or SP6 RNA polymerase and the Riboprobe Gemini System II reagent system (Promega Corp., Madison, WI).

\section{Statistical analyses}

The significance of treatments was assessed by analysis of variance (Gill, 1978). Differences between treatment means were tested for significance using Duncan's multiple range test. During assessment of gonadotrope responsiveness high amplitude GnRH stimulation was continued for $24 \mathrm{~h}$. However, pretreatment concentrations of $\mathrm{LH}$ and FSH were re-established 12 and $6 \mathrm{~h}$ after stimulus-shift, respectively. Therefore, the total amount of LH or FSH released during the first $12 \mathrm{~h}$ or $6 \mathrm{~h}$, respectively, after stimulus-shift was taken as a measure of gonadotrope responsiveness.

\section{Results}

\section{Experiment 1}

Gonadotrope responsiveness was significantly $(P<0.05)$ increased within $6 \mathrm{~h}$ of initiation of oestradiol infusion and circhoral delivery of low amplitude GnRH (Fig. I and Table 1). Extending the duration of treatment resulted in further increases in the magnitude of LH secretion during high amplitude GnRH stimulation. Continuous infusion of oestradiol 
Table 1. Effect of duration of a simulated follicular phase on the magnitude of gonadotrophin secretion induced by a circhoral high amplitude GnRH stimulus in orchidectomized sheep (wethers)

\begin{tabular}{lcc}
\hline $\begin{array}{l}\text { Duration of simulated } \\
\text { follicular phase }(\mathrm{h})^{\mathrm{a}}\end{array}$ & $\left.\begin{array}{c}\mathrm{LH}^{\mathrm{b}} \\
(\mathrm{ng} \mathrm{ml}\end{array}{ }^{-1}(12 \mathrm{~h})^{-1}\right)$ & $\begin{array}{c}\mathrm{FSH}^{\mathrm{b}} \\
\left(\mathrm{ng} \mathrm{ml}{ }^{-1}(6 \mathrm{~h})^{-1}\right.\end{array}$ \\
\hline 0 & $57.8 \pm 14.5^{\mathrm{c}}$ & $0.7 \pm 0.1^{\mathrm{c}}$ \\
6 & $193.4 \pm 10.5^{\mathrm{d}}$ & $7.5 \pm 1.0^{\mathrm{d}}$ \\
12 & $236.0 \pm 36.2^{\mathrm{d}}$ & $9.9 \pm 1.5^{\mathrm{d}}$ \\
24 & $249.2 \pm 25.9^{\mathrm{d}}$ & $8.9 \pm 0.8^{\mathrm{d}}$ \\
48 & $278.3 \pm 17.5^{\mathrm{d}}$ & $8.8 \pm 0.7^{\mathrm{d}}$ \\
96 & $396.5 \pm 63.6^{\mathrm{c}}$ & $8.2 \pm 1.4^{\mathrm{d}}$
\end{tabular}

A simulated follicular phase was established in wethers by continuous infusion of oestradiol $\left(5 \mu \mathrm{g} \mathrm{h}^{-1}\right)$ and episodic delivery of low amplitude GnRH (200 ng per hourly pulse) for $0,6,12,24,48$, or $96 \mathrm{~h}$.

${ }^{h}$ Area under the secretory profile of LH and FSH, in excess of basal secretion, during circhoral delivery of high amplitude GnRH (1600 ng per hourly pulse). The total amount of LH or FSH released during the first $12 \mathrm{~h}$ or $6 \mathrm{~h}$, respectively, after stimulus-shift was taken as a measure of gonadotrope responsiveness. Values are presented as means $\pm \operatorname{SEM}(n=6$ animals per group). ${ }^{c-c} V$ Values in a column that do not share a common superscript are significantly different $(P<0.05)$.

and episodic administration of low amplitude GnRH resulted in a tenfold increase $(P<0.05)$ in the magnitude of FSH secretion induced at stimulus-shift (Table 1). In contrast to the secretory response of $\mathrm{LH}$, the magnitude of high amplitude GnRHinduced FSH secretion did not vary with duration of simulated follicular phase.

\section{Experiment 2}

Serum concentrations of $\mathrm{LH}\left(13.4 \pm 1.8 \mathrm{ng} \mathrm{ml}^{-1}\right)$ and $\mathrm{FSH}$ $\left(14.9 \pm 0.7 \mathrm{ng} \mathrm{ml}^{-1}\right)$ in control wethers infused with the oestradiol delivery vehicle and receiving hourly pulses of saline for $96 \mathrm{~h}$ did not differ $(P>0.05)$ from pretreatment values (13.6 $\pm 1.2 \mathrm{ng} \mathrm{ml}^{-1}$ and $15.1 \pm 0.6 \mathrm{ng} \mathrm{ml}^{-1}$ for LH and FSH, respectively). In contrast, serum concentrations of $\mathrm{LH}$ and $\mathrm{FSH}$ were decreased $(P<0.05)$ in wethers receiving oestradiol and hourly pulses of saline (Fig. 2). Serum concentrations of LH were decreased by $50 \%\left(6.6 \pm 0.8 \mathrm{ng} \mathrm{ml}^{-1}\right)$ within $8 \mathrm{~h}$ of initiation of infusion and remained at that concentration for the duration of oestradiol delivery. Serum concentrations of FSH were significantly reduced within $4 \mathrm{~h}$ of initiation of infusion and continued to decrease gradually throughout the remainder of oestradiol delivery. The magnitude of the oestradiol-induced decrease in serum concentrations of FSH was not affected $(P>0.05)$ by episodic delivery of low amplitude GnRH. In contrast, the pattern of LH secretion during oestradiol infusion and concurrent delivery of low amplitude GnRH (200 ng per hourly pulse) was biphasic. Serum concentrations of LH were significantly decreased during the early period of combined oestradiol and $\mathrm{GnRH}$ treatment, with serum concentrations of LH reaching a nadir $\left(6.3 \pm 0.7 \mathrm{ng} \mathrm{ml}^{-1}\right) 10 \mathrm{~h}$ after initiation of the combined treatment. Serum concentrations of LH increased thereafter and returned to pretreatment concentrations $36 \mathrm{~h}$ $\left(13.1 \pm 2.0 \mathrm{ng} \mathrm{ml}^{-1}\right)$ after initiation of oestradiol infusion and circhoral administration of low amplitude GnRH (Fig. 2).
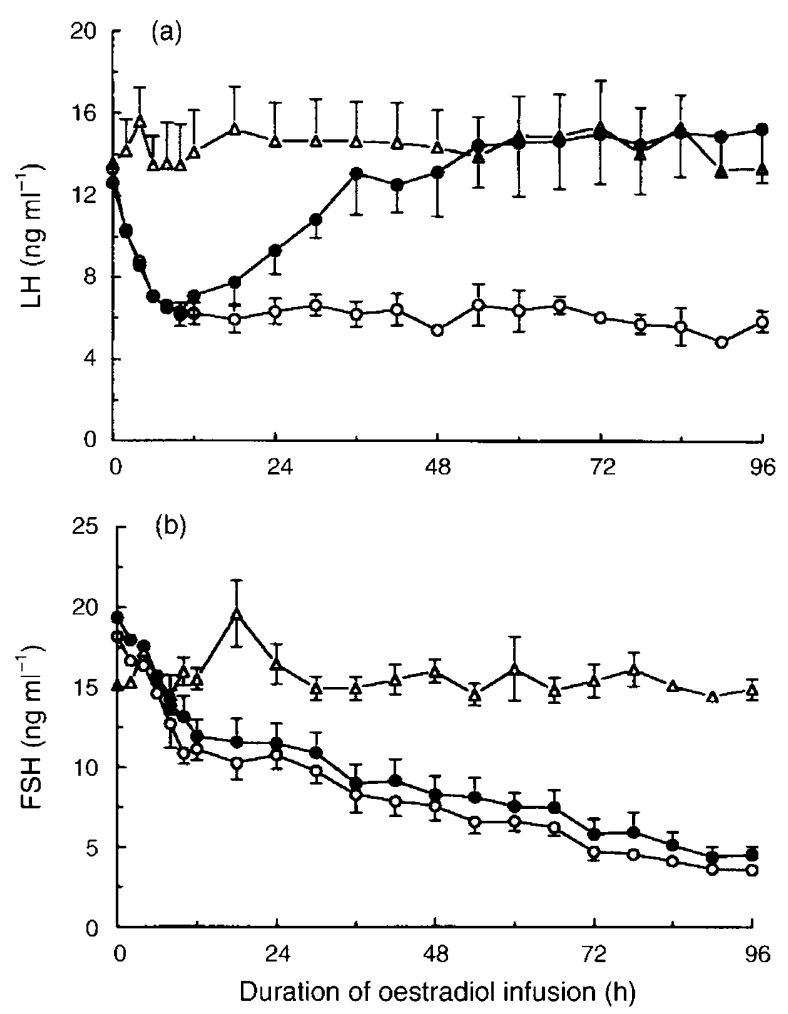

Fig. 2. Serum concentrations of (a) LH and (b) FSH in wethers $(n=6$ animals per group) during continuous infusion of oestradiol $(5 \mu \mathrm{g}$ $\mathrm{h}^{-1}$ ) and concurrent episodic delivery of saline $(O)$ or low amplitude GnRH (200 ng per hourly pulse; $)$. Control wethers $(\Delta)$ received oestradiol delivery vehicle and hourly pulses of saline during the $96 \mathrm{~h}$ infusion period.

High amplitude GnRH stimulation (stimulus-shift) induced surge-like secretion of $\mathrm{LH}$ in wethers receiving continuous infusion of oestradiol for $96 \mathrm{~h}$ (Fig. 3). In contrast, high amplitude $\mathrm{GnRH}$ stimulation was unable to elicit surge-like release of $\mathrm{LH}$ in wethers infused with vehicle alone. The magnitude of $\mathrm{LH}$ release in response to stimulus-shift in wethers receiving oestradiol infusion and low-amplitude GnRH (200 ng per hourly pulse) stimulation was significantly $(P<0.05)$ reduced, relative to the $\mathrm{LH}$ response in wethers receiving oestradiol alone during the $96 \mathrm{~h}$ before stimulus-shift (Fig. 3).

\section{Experiment 3}

Oestradiol infusion alone or in combination with circhoral delivery of GnRH resulted in a fourfold increase in tissue concentrations of GnRH receptor and mRNA encoding the GnRH receptor (Fig. 4). Similarly, the concentration of LH in the pituitary tissue of wethers receiving oestradiol or the oestradiol and GnRH combination for $96 \mathrm{~h}$ was significantly greater than the tissue concentration of $\mathrm{LH}$ in control animals (Fig. 5). The magnitude of the oestradiol-induced augmentation of tissue concentrations of GnRH receptor or LH stores was not significantly affected by concurrent delivery of low amplitude GnRH pulses. In contrast, tissue concentrations of FSH and steady state amounts of mRNA encoding the FSH $\beta$ subunit 


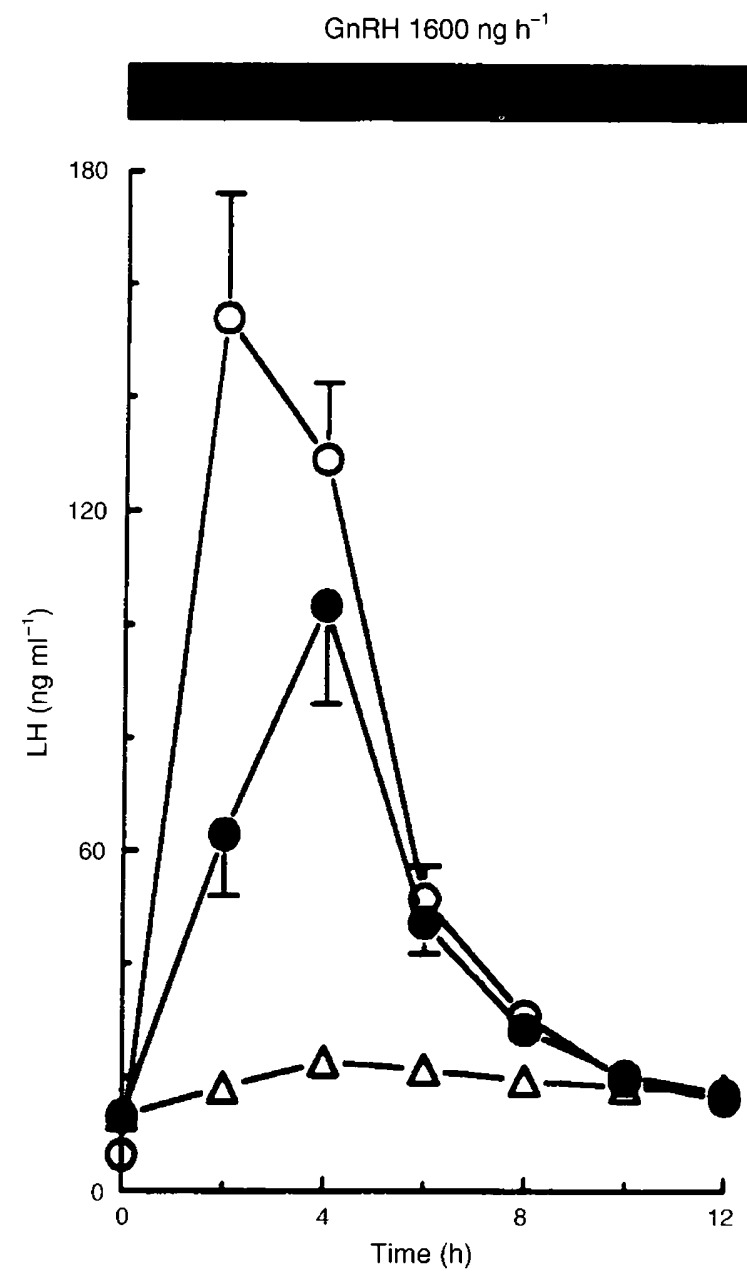

Fig. 3. Serum concentrations of LH in wethers during circhoral delivery of high amplitude GnRH (1600 ng per hourly pulse; stimulusshift). Wethers ( $n=6$ animals per group) received oestradiol ( $5 \mu \mathrm{g}$ $\mathrm{h}^{-1}$ ) and hourly pulses of saline (O) or low amplitude GnRH (200 ng per hourly pulse; ) during the $96 \mathrm{~h}$ period preceding stimulus-shift. Control wethers $(\triangle)$ were infused with oestradiol delivery vehicle and received hourly pulses of saline during the $96 \mathrm{~h}$ period preceding stimulus-shift.

were significantly $(P<0.05)$ decreased after 96 h of oestradiol infusion (Fig. 6). The reduction in FSH and mRNA for the FSH $\beta$ subunit was not affected $(P>0.05)$ by concurrent delivery of low amplitude GnRH. Neither oestradiol nor the oestradiol and low amplitude GnRH combination had a significant effect on steady state amounts of mRNA for the LH (Fig. 5). Similarly, the tissue concentration of mRNA encoding the $\alpha$ subunit in wethers receiving oestradiol $\left(41.7 \pm 5.3 \mathrm{pg}^{\mathrm{g}} \mathrm{g}^{-\mathrm{I}}\right.$ total RNA) or the oestradiol and GnRH combination $\left(34.1 \pm 7.3{\mathrm{pg} \mu \mathrm{g}^{-i}}^{-i}\right.$ total RNA) for $96 \mathrm{~h}$ did not differ $(P>0.05)$ from the amount of mRNA for the $\alpha$ subunit in pituitary tissue of control animals

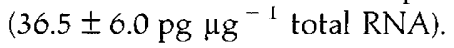

\section{Discussion}

We have previously demonstrated that an eightfold increase in the amplitude of hourly pulses of $\mathrm{GnRH}$ produces preovulatory

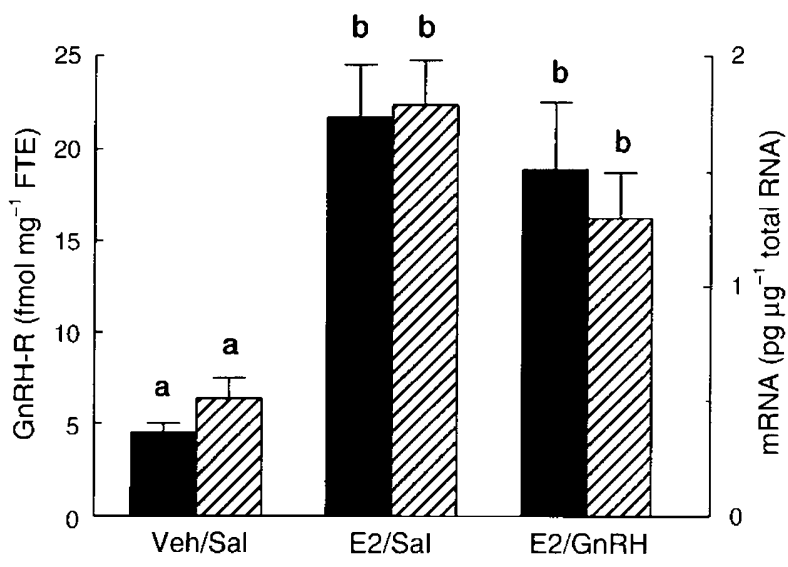

Fig. 4. Concentrations of ( $\square) \mathrm{GnRH}$ receptor (GnRH-R) and ( $\triangle A)$ mRNA encoding the GnRH receptor in pituitary tissue of wethers ( $n=6$ animals per group) after $96 \mathrm{~h}$ of continuous infusion of oestradiol ( $\left.5 \mu \mathrm{g} \mathrm{h}^{-i}\right)$ and concurrent episodic delivery of saline (E2/Sal) or low amplitude GnRH (200 ng per hourly pulse; E2/GnRH). Control wethers (Veh/Sal) were infused with oestradiol delivery vehicle and received hourly pulses of saline during the $96 \mathrm{~h}$ period preceding tissue collection. FTE: fresh tissue equivalent.

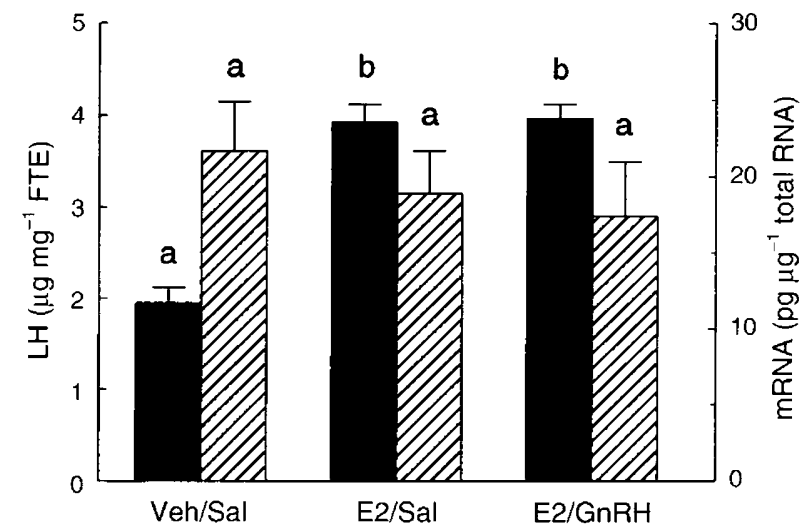

Fig. 5. Concentrations of ( $\boldsymbol{\square}) \mathrm{LH}$ and ( $(\pi)$ mRNA for the LH $\beta$ subunit in pituitary tissue of wethers ( $n=6$ animals per group) after $96 \mathrm{~h}$ of infusion of oestradiol $\left(5 \mu \mathrm{g} \mathrm{h}^{-1}\right)$ and concurrent episodic delivery of saline (E2/Sal) or low amplitude GnRH (200 ng per hourly pulse; E2/GnRH). Control wethers (Veh/Sal) were infused with oestradiol delivery vehicle and received hourly pulses of saline during the $96 \mathrm{~h}$ period preceding tissue collection. FTE: fresh tissue equivalent.

surge-like secretion of $\mathrm{LH}$ in wethers receiving oestradiol (Sakurai et al., 1993a). The physiological relevance of this 'stimulus-shift' pattern of GnRH delivery has been confirmed in female sheep passively immunized against GnRH (Sakurai et al., 1992). Oestrogenic input appears to be critical for full expression of the GnRH-induced surge, since the stimulus-shift pattern of $\mathrm{GnRH}$ or $\mathrm{GnRH}$ agonist delivery is unable to effect surge-like secretion of $\mathrm{LH}$ in wethers or ewes in the absence of concurrent endogenous or exogenous oestradiol stimulation (Sakurai et al., 1992, 1993a). Similarly, the magnitude of the GnRH-induced surge rapidly decays after withdrawal of oestrogenic support (Sakurai et al., 1993b). The experiments reported here examine the effect of duration of oestrogenic exposure on the magnitude of the $\mathrm{LH}$ and FSH surges induced by stimulus-shift. 


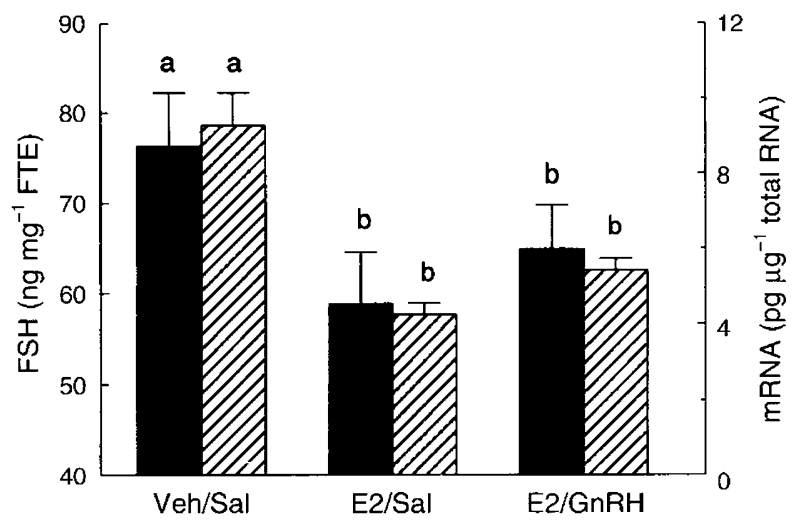

Fig. 6. Concentrations of (a) FSH and (ש $\mathbb{a})$ mRNA for the FSH $\beta$ subunit in pituitary tissue of wethers ( $n=6$ animals per group) after $96 \mathrm{~h}$ of continuous infusion of oestradiol $\left(5 \mu \mathrm{g} \mathrm{h}^{-1}\right)$ and concurrent episodic delivery of saline (E2/Sal) or low amplitude GnRH (200 ng per hourly pulse; E2/GnRH). Control wethers (Veh/Sal) were infused with oestradiol delivery vehicle and received hourly pulses of saline during the $96 \mathrm{~h}$ period preceding tissue collection. FTE: fresh tissue equivalent.

These studies demonstrate that the magnitude of secretion of LH induced at stimulus-shift increases with duration of oestrogenic exposure. This confirms and extends our previous observations (Sakurai et al., 1993a) and is consistent with the response to extended oestrogenic stimulation noted in women (Keye and Jaffe, 1975) and cattle (Kesner et al., 1981). However, these results are in contrast to the oestrogenic response reported using ovine pituitary cells in culture. Miller and co-workers (Miller and Huang, 1985; Laws et al., 1990) noted that the responsiveness of gonadotrope cells was first increased, then markedly reduced, during extended ( $>24 \mathrm{~h}$ ) culture in oestradiol-containing media. This biphasic response to oestradiol stimulation noted in vitro has led to the suggestion that oestradiol stimulation plays a critical role in both the initiation and termination of the ovulatory surge of gonadotrophins (Laws et al., 1990). The studies detailed here serve to emphasize the importance of oestradiol in initiation of the preovulatory surge. However, our results, using an in vivo model, do not support the contention that prolonged exposure to oestradiol leads to a diminution of gonadotrope responsiveness. Indeed, in our studies oestrogenic stimulation consistently enhanced gonadotrope responsiveness, regardless of duration of exposure. This finding suggests that the descending limb of the ovulatory surge is not driven by direct inhibitory effects of oestradiol. Rather, the reduction in gonadotrope responsiveness during the descending limb of the LH surge may reflect $\mathrm{GnRH}$-induced depletion of pituitary stores of $\mathrm{LH}$, downregulation of the $\mathrm{GnRH}$ receptor, or desensitization of a second messenger system or a combination of these effects (Sakurai et al., 1993a; Adams et al., 1996).

The direct contribution of low amplitude GnRH stimulation to augmentation of gonadotrope responsiveness during the natural or simulated follicular phase has not been clearly defined. Episodic delivery of $\mathrm{GnRH}$ is required to maintain gonadotrope function. Indeed, tissue concentrations of $\mathrm{LH}$ and FSH, steady state concentrations of mRNA coding for the gonadotrophin subunits, and tissue content of $\mathrm{GnRH}$ receptor are decreased after hypothalamo-pituitary disconnection (HPD;
Hamernik et al., 1986), administration of a GnRH antagonist (Sanchez et al., 1994) or immunoneutralization of GnRH (Sakurai and Adams, unpublished). Moreover, these measures of gonadotrope function are restored in HPD sheep by pulsatile delivery of GnRH (Hamernik and Nett, 1988). However, the studies reported here demonstrate that the magnitude of the LH surge induced at stimulus-shift is reduced in wethers receiving low amplitude GnRH stimulation. Circhoral administration of low amplitude GnRH during the simulated follicular phase may reduce the magnitude of the surge induced at stimulus-shift by mobilizing, and thus depleting, the LH in a readily releasable intracellular pool.

Although gonadotrope responsiveness was enhanced during oestradiol stimulation, gonadotrophin secretion was depressed during the period of oestradiol delivery. The oestradiolinduced decrease in gonadotrophin secretion is likely to reflect oestrogenic action at hypothalamic loci to reduce secretion of GnRH (Tilbrook et al., 1991; Tilbrook and Clarke, 1995), since episodic delivery of exogenous GnRH restored LH secretion and serum concentrations of LH. It is likely that oestradiolinduced augmentation of gonadotrope responsiveness is due, at least in part, to replenishment of readily releasable pools of LH during oestradiol-dependent suppression of gonadotrophin secretion.

Continuous infusion of oestradiol for $96 \mathrm{~h}$ resulted in a marked increase in the concentration of $\mathrm{GnRH}$ receptor and mRNA encoding the GnRH receptor in pituitary tissue. This oestradiol-induced response in wethers is comparable to the change in tissue content of GnRH receptor and mRNA for the GnRH receptor noted in oestradiol-treated ovariectomized sheep (Turzillo et al., 1994). The oestradiol-induced increase in tissue content of $\mathrm{GnRH}$ receptor and mRNA for the $\mathrm{GnRH}$ receptor noted in these studies is likely to reflect, at least in part, direct action of oestradiol at pituitary loci since the oestrogen-stimulated response is noted in sheep with HPD (Turzillo et al., 1995). A similar oestrogenic response has also been noted in sheep in which hypothalamic inputs have been negated by passive immunization (Adams and Sakurai, unpublished) or prolonged administration of a $\mathrm{GnRH}$ antagonist (Brooks and McNeilly, 1994). Oestrogen-induced augmentation of GnRH receptor and mRNA for the GnRH receptor has also been noted in vitro, using ovine pituitary cells in culture (Sealfon et al., 1990; Wu et al., 1994).

Physiological concentrations of oestradiol markedly depressed tissue content of mRNA for the FSH $\beta$ subunit, but had no effect on steady-state content of mRNA for the $\alpha$ and $\mathrm{LH} \beta$ subunits. This is consistent with previous studies (Sakurai et al., 1993a, b). In the study reported here the suppressive effect of oestradiol on tissue content of mRNA for the FSH $\beta$ subunit is not reversed by the concurrent delivery of low amplitude $\mathrm{GnRH}$. A similar response to oestrogenic stimulation has been noted in HPD sheep receiving exogenous GnRH (Mercer et al., 1988; 1989). These results indicate that oestradiol acts directly at hypophyseal loci to modulate FSH $\beta$ gene transcription or the stability of mRNA for the FSH $\beta$ subunit or both processes.

The results of these studies suggest that the magnitude of the gonadotrophin surge that is induced at stimulus-shift is primarily determined by the extent of oestrogenic stimulation. Increasing the duration of oestradiol stimulation appears to 
enhance responsiveness and the magnitude of the surge. Pulses of low amplitude GnRH during the simulated follicular phase lessen the magnitude of surge-like secretion induced by stimulus-shift, perhaps by reducing the $\mathrm{LH}$ resident in a readily releasable pool. However, circhoral low amplitude $\mathrm{GnRH}$ stimulation is likely to play a critical physiological role during the periovulatory period, since this pattern of $\mathrm{GnRH}$ stimulation is required to sustain gonadotrophin secretion adequate to promote follicular growth and development and oestradiol secretion.

Supported by USDA Grant 93-37202-9111 and the California Agricultural Experiment Station.

\section{References}

Adams BM, Sakurai H and Adams TE (1996) Concentrations of gonadotropinreleasing hormone (GnRH) receptor messenger ribonucleic acid in pituitary tissue of orchidectomized sheep: effect of estradiol and GnRH Biology of Reproduction 54 407-412

Adams TE, Kinder JE, Chakraborty PK, Estergreen VL and Reeves JJ (1975) Ewe luteal function influenced by pulsatile administration of synthetic LHRH/ FSHRH Endocrinology 97 1460-1467

Adams TE, Quirke JF, Hanrahan JP, Adams BM and Watson JG (1988) Gonadotrophin secretion during the periovulatory period in Galway and Finnish Landrace ewes and Finnish Landrace ewes selected for high ovulation rate Journal of Reproduction and Fertility 83 575-584

Brooks J and McNeilly AS (1994) Regulation of gonadotrophin-releasing hormone receptor mRNA expression in the sheep Journal of Endocrinology 143 175-182

Brooks J, Taylor PL, Saunders PT, Eidne KA, Struthers WJ and McNeilly AS (1993) Cloning and sequencing of the sheep pituitary gonadotropin-releasing hormone receptor and changes in expression of its mRNA during the estrous cycle Molecular and Cellular Endocrinology 94 R23-R27

Clarke IJ and Cummins JT (1987) The significance of small pulses of gonadotrophin-releasing hormone Journal of Endocrinology 113 413-418

Erwin CR, Croyle ML, Donelson JE and Maurer RA (1983) Nucleotide sequence of cloned complementary deoxyribonucleic acid for the $\alpha$ subunit of bovine pituitary glycoprotein hormones Biochemistry 22 4856-4860

Gill JL (1978) Design and Analysis of Experiments in the Animal and Medical Sciences Iowa State University Press, Ames, IA

Hamernik DL and Nett TM (1988) Gonadotropin-releasing hormone increases the amount of messenger ribonucleic acid for gonadotropins in ovariectomized ewes after hypothalamic-pituitary disconnection Endocrinology 122 959-966

Hamernik DL, Crowder ME, Nilson JH and Nett TM (1986) Measurement of messenger ribonucleic acid for luteinizing hormone $\beta$-subunit, $\alpha$-subunit, growth hormone, and prolactin after hypothalamic pituitary disconnection in ovariectomized ewes Endocrinology 119 2704-2710

Kesner JS, Convey EM and Anderson CR (1981) Evidence that estradiol induces the preovulatory LH surge in cattle by increasing pituitary sensitivity to LHRH and then increasing LHRH release Endocrinology 108 1386-1391

Keye WR and Jaffe RB (1975) Strength-duration characteristics of estrogen effects on gonadotropin response to gonadotropin-releasing hormone in women. I. Effects of varying duration of estradiol administration Journal of Clinical Endocrinology and Metabolism 41 1003-1008

Laws SC, Webster JC and Miller WL (1990) Estradiol alters the effectiveness of gonadotropin-releasing hormone $(\mathrm{GnRH})$ in ovine pituitary cultures: $\mathrm{GnRH}$ receptors versus responsiveness to $\mathrm{GnRH}$ Endocrinology 127 381-386

Leung K, Kaynard AH, Negrini BP, Kim KE, Maurer RA and Landefeld TD (1987) Differential regulation of gonadotropin subunit messenger ribonucleic acids by gonadotropin-releasing hormone pulse frequency in ewes Molecular Endocrinology 1 724-728
Maurer RA (1985) Analysis of several bovine lutropin $\beta$ subunit cDNAs reveals heterogeneity in the nucleotide sequence Journal of Biological Chemistry $2604684-4687$

Maurer RA and Beck A (1986) Isolation and nucleotide sequence analysis of a cloned CDNA encoding the $\beta$-subunit of bovine follicle-stimulating hormone DNA 5 363-369

Mercer JE, Clements JA, Funder JW and Clarke IJ (1988) Luteinizing hormone- $\beta$ mRNA levels are regulated primarily by gonadotropin-releasing hormone and not by negative estrogen feedback on the pituitary Neuroendocrinology $47563-566$

Mercer JE, Clements JA, Funder JW and Clarke IJ (1989) Regulation of folliclestimulating hormone $\beta$ and common $\alpha$-subunit messenger ribonucleic acid by gonadotropin-releasing hormone and estrogen in the sheep pituitary Neuroendocrinology 50 321-326

Miller WL and Huang ES (1985) Secretion of ovine luteinizing hormone in vitro differential positive control by $17 \beta$-estradiol and a preparation of porcine ovarian inhibin Endocrinology 117 907-911

Moenter SM, Caraty A and Karsch FJ (1990) The estradiol-induced surge of gonadotropin-releasing hormone in the ewe Endocrinology 127 1375-1384

Moenter SM, Caraty A, Locatelli A and Karsch FJ (1991) Pattern of gonadotropin-releasing hormone $(\mathrm{GnRH})$ secretion leading up to ovulation in the ewe: existence of a preovulatory $\mathrm{GnRH}$ surge Endocrinology 129 $1175-1182$

Phillips DJ, Cummins JT and Clarke IJ (1990) Effects of modifying gonadotrophin-releasing hormone input before and after oestrogen-induced LH surge in ovariectomized ewes with hypothalamo-pituitary disconnection Journal of Endocrinology 127 223-233

Sakurai H and Adams TE (1991) Gonadotrope responsiveness in orchidectomized sheep: I. Effect of continuous infusion of estradiol Biology of Reproduction 45 804-810

Sakurai H, Adams BM and Adams TE (1992) Pattern of gonadotropin-releasing hormone (GnRH)-like stimuli sufficient to induce follicular growth and ovulation in ewes passively immunized against GnRH Biology of Reproduction $47 \quad 177-184$

Sakurai H, Adams BM and Adams TE (1993a) Gonadotrope responsiveness in orchidectomized sheep. III. Effect of estradiol withdrawal after continuous infusion Biology of Reproduction 49 1019-1025

Sakurai H, Adams BM, Oberbauer AM and Adams TE (1993b) Gonadotrope responsiveness in orchidectomized sheep. II. Effect of gonadotropinreleasing hormone amplitude shift during continuous infusion of estradiol Biology of Reproduction $\mathbf{4 8}$ 683-691

Sanchez T, Wehrman ME, Moss GE, Kojima FN, Cupp AS, Bergfeld EG, Peters KE, Mariscal V, Grotjan HE, Kinder JE and Hamernik DL (1994) Differential regulation of gonadotropin synthesis and release in ovariectomized ewes after treatment with a luteinizing hormone-releasing hormone antagonist Biology of Reproduction $\mathbf{5 1}$ 755-759

Sealfon SC, Laws SC, Wu JC, Gillo B and Miller WL (1990) Hormonal regulation of gonadotropin-releasing hormone receptors and messenger RNA activity in ovine pituitary culture Molecular Endocrinology 4 1980-1987

Tilbrook AJ and Clarke IJ (1995) Negative feedback regulation of the secretion and actions of $\mathrm{GnRH}$ in male ruminants Journal of Reproduction and Fertility Supplement 49 297-306

Tilbrook AJ, deKretser DM, Cummins JT and Clarke IJ (1991) The negative feedback effects of testicular steroids are predominantly at the hypothalamus in the ram Endocrinology 129 3080-3092

Turzillo AM, Campion CE, Clay CM and Nett TM (1994) Regulation of gonadotropin-releasing hormone $(\mathrm{GnRH})$ receptor messenger ribonucleic acid and GnRH receptors during the early preovulatory period in the ewe Endocrinology 135 1353-1358

Turzillo AM, DiGregorio GB and Nett TM (1995) Messenger ribonucleic acid for gonadotropin-releasing hormone receptor and numbers of gonadotropinreleasing hormone receptors in ovariectomized ewes after hypothalamicpituitary disconnection and treatment with estradiol Journal of Animal Science $73 \quad 1784-1788$

Wu JC, Sealfon SC and Miller WL (1994) Gonadal hormones and gonadotropinreleasing hormone ( $\mathrm{GnRH}$ ) alter messenger ribonucleic acid levels for $\mathrm{GnRH}$ receptors in sheep Endocrinology 134 1846-1850 